\title{
Angustibacter luteus gen. nov., sp. nov., isolated from subarctic forest soil
}

\author{
Tomohiko Tamura, ${ }^{1}$ Yuumi Ishida, ${ }^{1}$ Misa Otoguro, ${ }^{1}$ Hideki Yamamura, ${ }^{2}$ \\ Masayuki Hayakawa ${ }^{2}$ and Ken-ichiro Suzuki ${ }^{1}$ \\ ${ }^{1}$ NITE Biological Resource Center (NBRC), National Institute of Technology and Evaluation, \\ 2-5-8 Kazusakamatari, Kisarazu, Chiba 292-0818, Japan \\ ${ }^{2}$ Faculty of Engineering, University of the Yamanashi, 4-3-11, Takeda, Kofu, \\ Yamanashi 400-8511, Japan
}

Tomohiko Tamura

tamura-tomohiko@nite.go.jp

The family 'Kineosporiaceae' (Garrity et al., 2007) was described as one of six families belonging to the suborder Frankineae, which accommodated the genera Cryptosporangium (Tamura et al., 1998), Kineococcus (Yokota et al., 1993) and Kineosporia (Pagani \& Parenti, 1978). However, Carlsohn et al. (2008) reported that the family 'Kineosporiaceae' did not emerge as a phylogenetically coherent family. Subsequently, Zhi et al. (2009) proposed the new suborder Kineosporiineae and the valid family Kineosporiaceae for accommodating the genera Kineococcus, Kineosporia and Quadrisphaera (Maszenan et al., 2005), and the new family Cryptosporangiaceae in the suborder Frankineae for the genus Cryptosporangium based on $16 \mathrm{~S}$ rRNA gene sequence analysis. The genus Kineosporia forms elongating, club-shaped sporangia containing motile cells, the genus Kineococcus forms motile cocci, and the genus Quadrisphaera forms non-motile cocci.

Strain TT07R-79 ${ }^{\mathrm{T}}$ was isolated from broad-leaf forest soil on Rishiri Island, Hokkaido, Japan, in 2007. Strain TT07R-79 ${ }^{\mathrm{T}}$ was isolated by using the yeast extract-SDS method (Hayakawa \& Nonomura, 1989) on HV medium (Hayakawa \& Nonomura, 1987) containing $20 \mathrm{mg}$ nalidixic acid $\mathrm{l}^{-1}$ and $50 \mathrm{mg}$ cycloheximide $1^{-1}$.

PCR amplification and sequencing of the 16S rRNA gene were performed as described previously (Tamura \&

The GenBank/EMBL/DDBJ accession number for the $16 \mathrm{~S}$ rRNA gene sequence of strain TT07R-79 ${ }^{\top}$ is AB512285.

A phylogenetic tree derived from $16 \mathrm{~S}$ rRNA gene sequences of strain TT07R-79 ${ }^{\top}$ and representatives of the order Actinomycetales is available with the online version of this paper.
Hatano, 2001). The identification of phylogenetic neighbours and calculation of pairwise $16 \mathrm{~S}$ rRNA gene sequence similarities were achieved by using the EzTaxon server (http://www.eztaxon.org/; Chun et al., 2007). The $16 \mathrm{~S}$ rRNA gene sequence was aligned with published sequences retrieved from the DDBJ by using CLUSTAL $\mathrm{x}$ (Thompson et al., 1997) and the alignment was manually edited by using BioEdit version 7.0.9 (Hall, 1999). Phylogenetic trees were reconstructed by using the neighbour-joining (Saitou \& Nei, 1987) and maximum-parsimony (Fitch, 1971) algorithms using the MEGA 4.1 program (Tamura et al., 2007). The resultant tree topologies were evaluated by bootstrap analysis (Felsenstein, 1985) based on 1000 replications.

Sequence comparisons with 16S rRNA gene sequences from the EzTaxon database (Chun et al., 2007) revealed that strain TT07R-79 ${ }^{\mathrm{T}}$ had highest sequence similarity with Oryzihumus leptocrescens $\mathrm{KV}-628^{\mathrm{T}}$ (94.95\%), Kineosporia rhamnosa JCM $9954^{\mathrm{T}}(94.76 \%)$, Ornithinicoccus hortensis HKI $0125^{\mathrm{T}}(94.66 \%)$, Knoellia sinensis DSM $12331^{\mathrm{T}}$ $(94.45 \%)$ and Kineococcus xinjiangensis $\mathrm{S} 2-20^{\mathrm{T}}$ (94.43\%), which belong to the family Kineosporiaceae in the suborder Kineosporiineae and the family Intrasporangiaceae in the suborder Micrococcineae. The relationship of strain TT07R$79^{\mathrm{T}}$ to members of the suborders Kineosporiineae and Micrococcineae can be seen in the phylogenetic tree reconstructed by using representatives of families of the order Actinomycetales shown in Supplementary Figure S1 (available in IJSEM Online). The 16S rRNA gene sequence analysis with related taxa, including the type species of the families Kineosporiaceae and Intrasporangiaceae, revealed 
that strain TT07R-79 ${ }^{\mathrm{T}}$ formed a monophyletic clade with the members of the suborder Kineosporiineae in neighbourjoining and maximum-parsimony phylogenetic trees (Fig. 1 ), but this branch was only supported by a low bootstrap value $(45 \%)$. With all treeing methods, strain TT07R-79 appeared as an individual line of descent (see Fig. 1 for the neighbour-joining dendrogram). In view of its phylogenetically deep branching point within the family Kineosporiaceae, strain TT07R-79 ${ }^{\mathrm{T}}$ should be considered to represent a novel genus.

Cell-wall amino acids, the acyl type of the peptidoglycan, the whole-cell sugar pattern, cellular fatty acids, mycolic acids, menaquinones and the DNA base composition were analysed as described previously (Tamura et al., 1994). Freeze-dried cells for chemotaxonomic analyses were prepared from cultures grown in yeast extract-glucose (YG) broth (Hatano et al., 2003) on a rotary shaker at $28{ }^{\circ} \mathrm{C}$ for 3 days. The predominant menaquinone was MK$9\left(\mathrm{H}_{4}\right)$, with MK-9 $\left(\mathrm{H}_{6}\right)$ as a minor component. Strain TT07R- $79^{\mathrm{T}}$ contained meso-diaminopimelic acid, alanine and glutamic acid in the cell wall, and galactose, glucose and ribose as whole-cell sugars. The fatty acid profile was characterized by a predominance of iso- $\mathrm{C}_{17: 0}(19.5 \%)$, iso$\mathrm{C}_{15: 0}(19.2 \%), \mathrm{C}_{16: 0}(18.4 \%)$ and the presence of smaller proportions of 9 methyl- $\mathrm{C}_{16: 0}(9.8 \%)$, anteiso- $\mathrm{C}_{17: 0}$ $(6.5 \%), \mathrm{C}_{18: 1} \omega 9 c(4.1 \%), \mathrm{C}_{17: 0}$ (3.7\%), 10 methyl- $\mathrm{C}_{17: 0}$ (3.5\%), $\mathrm{C}_{16: 1} 2-\mathrm{OH}(3.0 \%), \mathrm{C}_{17: 1} \omega 9 c(2.2 \%)$, iso- $\mathrm{C}_{18: 0}$ $(2.1 \%), \mathrm{C}_{18: 0}(2.0 \%), 10$ methyl- $\mathrm{C}_{18: 0}(1.9 \%)$, iso- $\mathrm{C}_{16: 0}$ $(1.7 \%)$, iso- $\mathrm{C}_{14: 0}(1.2 \%)$ and anteiso- $\mathrm{C}_{15: 0}(1.2 \%)$.
Diphosphatidylglycerol, phosphatidylglycerol, phosphatidylinositol and phosphatidylinositol mannoside were detected. The DNA G+C content was $70.9 \mathrm{~mol} \%$. Mycolic acids were absent. The acyl type of the cell-wall muramic acid was the acetyl type.

Morphological characteristics were observed by using scanning electron microscopy as described previously (Tamura et al., 1994). Strain TT07R-79 ${ }^{\mathrm{T}}$ formed spherical to rod-shaped cells, 0.3 to $0.5 \mu \mathrm{m}$ in diameter and 0.3 to $2.0 \mu \mathrm{m}$ long, sometimes up to $5 \mu \mathrm{m}$ long (Fig. 2). Cell motility was not observed in distilled water, $0.04 \% \mathrm{NaCl}$ solution or $0.01 \mathrm{M}$ phosphate buffer ( $\mathrm{pH}$ 7.0) with $1 / 10$ soil extract. Determination of the cultural and physiological characteristics was performed as described by Seino et al. (1985) and Shirling \& Gottlieb (1966) and by using API ZYM, API 50CH and API coryne test strips (bioMérieux). Good growth was observed on yeast extractmalt extract agar (ISP-2), oatmeal agar (ISP-3) and yeast extract-starch agar containing, per litre distilled water $(\mathrm{pH} 7.2), 15.0 \mathrm{~g}$ soluble starch, $4.0 \mathrm{~g}$ yeast extract, $0.5 \mathrm{~g}$ $\mathrm{K}_{2} \mathrm{HPO}_{4}, 0.5 \mathrm{~g} \mathrm{MgSO}_{4} .7 \mathrm{H}_{2} \mathrm{O}$ and $15.0 \mathrm{~g}$ agar. Colonies were circular, smooth, convex and orange in colour. Strain TT07R-79 ${ }^{\mathrm{T}}$ grew under both aerobic and anaerobic conditions. The $\mathrm{pH}$ range for growth was analysed by using filter-sterilized YG broth ( $\mathrm{pH}$ adjusted using $5 \mathrm{M}$ sulfuric acid). Strain TT07R-79 ${ }^{\mathrm{T}}$ grew optimally at $\mathrm{pH} 6$ to 7. Detailed results of these analyses are provided in the species description.

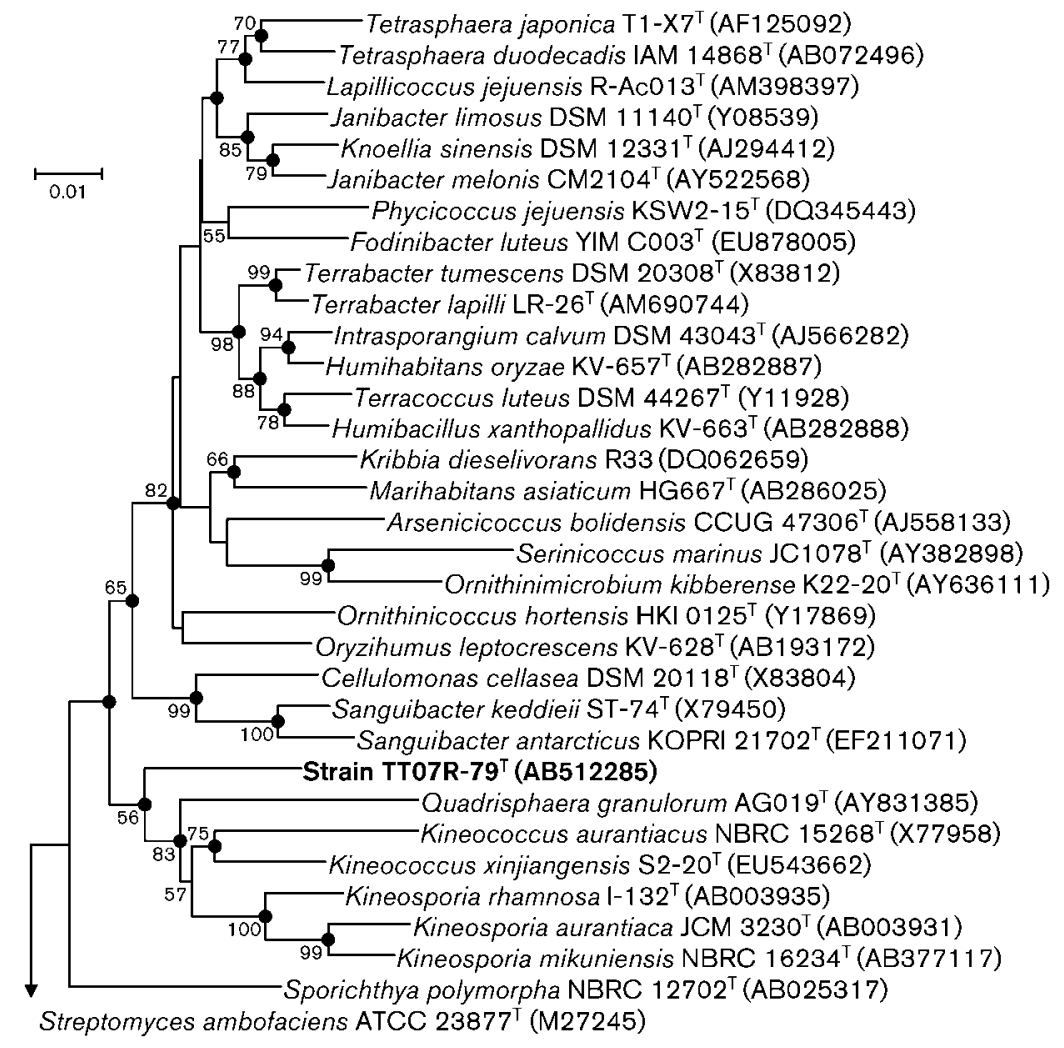

Fig. 1. Phylogenetic tree derived from $16 \mathrm{~S}$ rRNA gene sequences of strain TT07R-79 ${ }^{\top}$ and members of the suborder Kineosporiineae. The tree was reconstructed by using the neighbourjoining method based on $1326 \mathrm{bp}$ of the 16S rRNA gene sequence. The 16S rRNA gene sequence of Streptomyces ambofaciens (M27245) was used as the outgroup. Numbers on branches are confidence limits (expressed as percentages) estimated using bootstrap analysis with 1000 replicates; only values $>50 \%$ are provided. Solid circles indicate that the corresponding nodes (groupings) were also recovered in the maximum-parsimony tree. Bar, $0.01 \mathrm{nt}$ substitutions per site. 


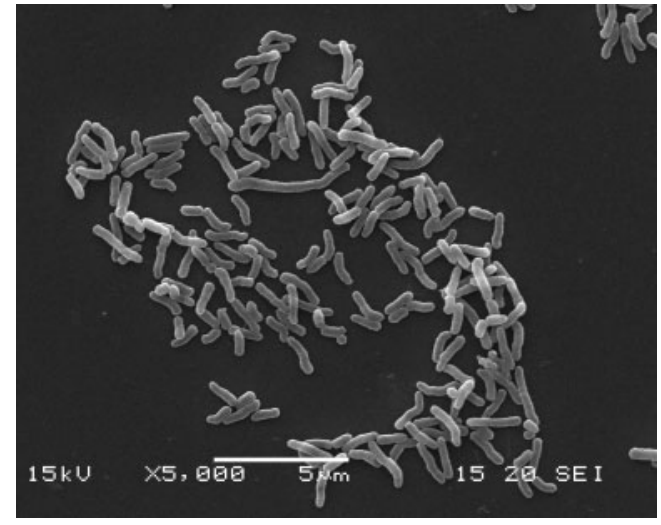

Fig. 2. Scanning electron micrograph of strain TT07R-79 ${ }^{\top}$ grown on ISP-2 at $28{ }^{\circ} \mathrm{C}$ for 5 days. Bar, $5 \mu \mathrm{m}$.

The colony colour of strain TT07R-79 ${ }^{\mathrm{T}}$ was orange, similar to those of Kineosporia and Kineococcus. However, strain TT07R-79 ${ }^{\mathrm{T}}$ was clearly different from those organisms in cell shape and motility. Strain TT07R $-79^{\mathrm{T}}$ was distinguishable from the related members of the suborder Kineosporiineae by some properties listed in Table 1 . Therefore, based on morphological, physiological and chemotaxonomic data and phylogenetic distinctiveness, strain TT07R-79 ${ }^{\mathrm{T}}$ should be assigned to a novel species of a new genus. The name Angustibacter luteus gen. nov., sp. nov. for strain TT07R-79 ${ }^{\mathrm{T}}$ (=NBRC $105387^{\mathrm{T}}=\mathrm{KACC}$ $\left.14249^{\mathrm{T}}\right)$ is proposed.

\section{Description of Angustibacter gen. nov.}

Angustibacter (An.gu.sti.bac'ter. L. adj. angustus narrow; N.L. masc. n. bacter a rod; N.L. masc. n. Angustibacter narrow bacterium).

Cells are Gram-positive, non-motile, non-spore-forming, facultatively anaerobic, catalase-positive cocci to rods. The peptidoglycan is of the A type (A $1 \gamma$ sensu; Schleifer \& Kandler, 1972) and contains meso-diaminopimelic acid, alanine and glutamic acid. Cell-wall sugars are galactose, glucose and ribose. Mycolic acids are absent. The major menaquinone is $\mathrm{MK}-9\left(\mathrm{H}_{4}\right)$. The phospholipids comprise diphosphatidylglycerol, phosphatidylglycerol, phosphatidylinositol and phosphatidylinositol mannoside. The cellular fatty acids are a complex mixture of straight-chain saturated, monounsaturated and iso- and anteiso-methylbranched acids and consist mainly of iso-methyl-branched saturated and straight-chain saturated acids, with iso$\mathrm{C}_{17: 0}$, iso- $\mathrm{C}_{15: 0}$ and $\mathrm{C}_{16: 0}$ predominating. The type species is Angustibacter luteus.

\section{Description of Angustibacter luteus sp. nov.}

Angustibacter luteus (lu'te.us. L. masc. adj. luteus orangecoloured).

Displays the properties of the genus with the following additions. Cells are usually $0.3-0.5 \mu \mathrm{m}$ wide and $0.3-$ $2.0 \mu \mathrm{m}$ long, and rarely up to $5 \mu \mathrm{m}$ long. Colonies are orange in colour. Growth occurs between 5 and $30{ }^{\circ} \mathrm{C}$. The $\mathrm{pH}$ range for growth is 6 to 8 (optimum 6 to 7). Growth

Table 1. Differential characteristics of strain TTO7R-79 ${ }^{\top}$ and related genera

Data from Groth et al. (1999, 2002), Itoh et al. (1989), Kageyama et al. (2005), Kudo et al. (1998), Maszenan et al. (2005), Tamura et al. (1998), Weon et al. (2007), Yokota et al. (1993) and this study. A 2 pm, diaminopimelic acid; Orn, ornithine; A, anteiso-methyl-branched; I, iso-methylbranched; M, 9- or 10-methyl-branched; S, straight-chain saturated; U, monounsaturated; DPG, diphosphatidylglycerol; GL, unknown glycolipid(s); PC, phosphatidylcholine; PE, phosphatidylethanolamine; PG, phosphatidylglycerol; PI, phosphatidylinositol; PIM, phosphatidylinositol mannosides; PL, unknown phospholipid(s); PS, phosphatidylserine; ND, no data.

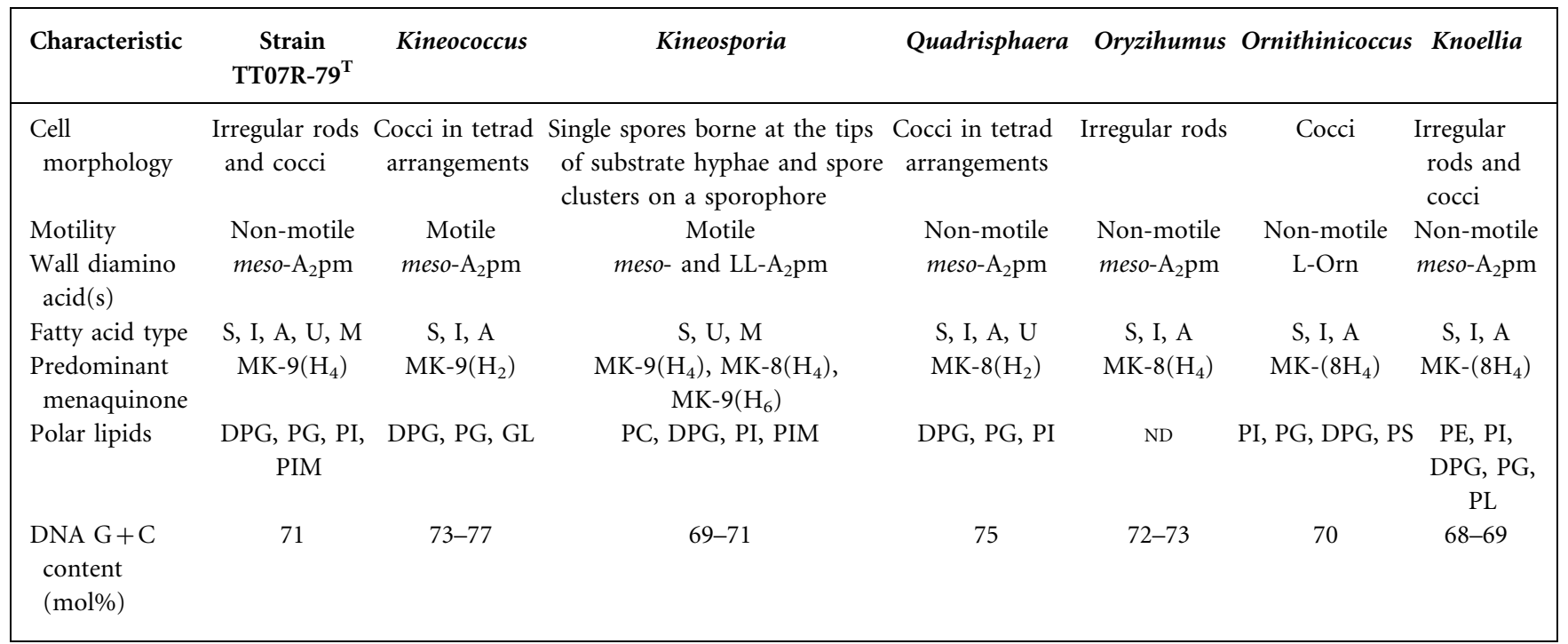


does not occur in the presence of $1 \%(\mathrm{w} / \mathrm{v}) \mathrm{NaCl}$ on yeast extract-starch agar. Negative for nitrate reduction. Arbutin, cellobiose, aesculin, ferric citrate, D-fructose, gentiobiose, D-glucose, glycerol, lactose, D-lyxose, maltose, D-mannose, melibiose, D-raffinose, L-rhamnose, D-ribose, salicin, starch, sucrose, trehalose, turanose and D-xylose are used as sole carbon source, but D-adonitol, amygdalin, Darabinose, L-arabinose, D-arabitol, L-arabitol, dulcitol, erythritol, D-fucose, L-fucose, D-galactose, 5-keto-gluconate, methyl $\alpha$-D-glucopyranoside, $N$-acetylglucosamine, glycogen, inositol, inulin, D-mannitol, D-melezitose, methyl $\alpha$-D-mannopyranoside, D-sorbitol, L-sorbose, D-tagatose, methyl $\beta$-D-xylopyranoside, xylitol and L-xylose are not assimilated. $\beta$-Galactosidase, $\alpha$-glucosidase, aesculin hydrolysis, gelatin hydrolysis, esterase lipase (C-8), leucine aminopeptidase, cystine aminopeptidase, acid phosphatase and $\alpha$-galactosidase are detected in the API ZYM enzyme assay; tests for pyrazinamidase, pyrrolidonyl arylamidase, $\beta$-glucuronidase, $N$-acetyl- $\beta$-glucosaminidase, urea hydrolysis, alkaline phosphatase, esterase (C-4), valine aminopeptidase, trypsin, chymotrypsin, phosphohydrolase, $\alpha$-mannosidase and $\alpha$-fucosidase are negative. The DNA $\mathrm{G}+\mathrm{C}$ content of the type strain is $70.9 \mathrm{~mol} \%$.

The type strain is strain TT07R-79 $\left(=\mathrm{NBRC} 105387^{\mathrm{T}}\right.$ $=$ KACC $14249^{\mathrm{T}}$ ).

\section{Acknowledgements}

This work was supported in part by a research grant from the Institute for Fermentation, Osaka (IFO).

\section{References}

Carlsohn, M. R., Groth, I., Saluz, H. P., Schumann, P. \& Stackebrandt, E. (2008). Fodinicola feengrottensis gen. nov., sp. nov., an actinomycete isolated from a medieval mine. Int J Syst Evol Microbiol 58, 1529-1536.

Chun, J., Lee, J.-H., Jung, Y., Kim, M., Kim, S., Kim, B. K. \& Lim, Y.-W. (2007). EzTaxon: a web-based tool for the identification of prokaryotes based on $16 \mathrm{~S}$ ribosomal RNA gene sequences. Int J Syst Evol Microbiol 57, 2259-2261.

Felsenstein, J. (1985). Confidence limits on phylogenies: an approach using the bootstrap. Evolution 39, 783-791.

Fitch, W. M. (1971). Toward defining the course of evolution: minimum change for a specific tree topology. Syst Zool 20, 406416.

Garrity, G. M., Lilburn, T. G., Cole, J. R., Harrison, S. H., Euzeby, J. \& Tindall, B. J. (2007). Part 10 - The Bacteria: phylum Actinobacteria: class 'Actinobacteria'. In The Taxonomic Outline of the Bacteria and Archaea. Release 7.7. http://www.taxonomicoutline.org/index.php/ toba/article/view/187/219.

Groth, I., Schumann, P., Martin, K., Schuetze, B., Augsten, K., Kramer, I. \& Stackebrandt, E. (1999). Ornithinicoccus hortensis gen. nov., sp. nov., a soil actinomycete which contains L-ornithine. Int $J$ Syst Bacteriol 49, 1717-1724.

Groth, I., Schumann, P., Schütze, B., Augsten, K. \& Stackebrandt, E. (2002). Knoellia sinensis gen. nov., sp. nov. and Knoellia subterranea sp. nov., two novel actinobacteria isolated from a cave. Int J Syst Evol Microbiol 52, 77-84.
Hall, T. A. (1999). BioEdit: a user-friendly biological sequence alignment editor and analysis program for Windows 95/98/NT. Nucleic Acids Symp Ser 41, 95-98.

Hatano, K., Nishii, T. \& Kasai, H. (2003). Taxonomic re-evaluation of whorl-forming Streptomyces (formerly Streptoverticillium) species by using phenotypes, DNA-DNA hybridization and sequences of gyrB, and proposal of Streptomyces luteireticuli (ex Katoh and Arai 1957) corrig., sp. nov., nom. rev. Int J Syst Evol Microbiol 53, 15191529.

Hayakawa, M. \& Nonomura, H. (1987). Humic acid-vitamin agar, a new medium for selective isolation of soil actinomycetes. $J$ Ferment Technol 65, 501-509.

Hayakawa, M. \& Nonomura, H. (1989). A new method for the intensive isolation of actinomycetes from soil. Actinomycetologica 3, 95-104.

Itoh, T., Kudo, T., Parenti, F. \& Seino, A. (1989). Amended description of the genus Kineosporia, based on chemotaxonomic and morphological studies. Int J Syst Bacteriol 39, 168-173.

Kageyama, A., Takahashi, Y., Seki, T., Tomoda, H. \& Omura, S. (2005). Oryzihumus leptocrescens gen. nov., sp. nov. Int J Syst Evol Microbiol 55, 2555-2559.

Kudo, T., Matsushima, K., Itoh, T., Sasaki, J. \& Suzuki, K. (1998). Description of four new species of the genus Kineosporia: Kineosporia succinea sp. nov., Kineosporia rhizophila sp. nov., Kineosporia mikuniensis sp. nov. and Kineosporia rhamnosa sp. nov., isolated from plant samples, and amended description of the genus Kineosporia. Int J Syst Bacteriol 48, 1245-1255.

Maszenan, A. M., Tay, J.-H., Schumann, P., Jiang, H.-L. \& Tay, S. T.-L. (2005). Quadrisphaera granulorum gen. nov., sp. nov., a Grampositive polyphosphate-accumulating coccus in tetrads or aggregates isolated from aerobic granules. Int J Syst Evol Microbiol 55, 17711777.

Pagani, H. \& Parenti, F. (1978). Kineosporia, a new genus of the order Actinomycetales. Int $J$ Syst Bacteriol 28, 401-406.

Saitou, N. \& Nei, M. (1987). The neighbor-joining method: a new method for reconstructing phylogenetic trees. Mol Biol Evol 4, 406425.

Schleifer, K. H. \& Kandler, O. (1972). Peptidoglycan types of bacterial cell walls and their taxonomic implications. Bacteriol Rev 36, 407477.

Seino, A., Arai, M., Enokita, R., Okazaki, T. \& Furuichi, A. (1985). Identification Manual of Actinomycetes. Tokyo: The Society for Actinomycetes Japan. (in Japanese)

Shirling, E. B. \& Gottlieb, D. (1966). Methods for characterization of Streptomyces species. Int J Syst Bacteriol 16, 313-340.

Tamura, T. \& Hatano, K. (2001). Phylogenetic analysis of the genus Actinoplanes and transfer of Actinoplanes minutisporangius Ruan et al. 1986 and 'Actinoplanes aurantiacus' to Cryptosporangium minutisporangium comb. nov. and Cryptosporangium aurantiacum sp. nov. Int $J$ Syst Evol Microbiol 51, 2119-2125.

Tamura, T., Nakagaito, Y., Nishii, T., Hasegawa, T., Stackebrandt, E. \& Yokota, A. (1994). A new genus of the order Actinomycetales, Couchioplanes gen. nov., with descriptions of Couchioplanes caeruleus (Horan and Brodsky 1986) comb. nov. and Couchioplanes caeruleus subsp. azureus subsp. nov. Int J Syst Bacteriol 44, 193203.

Tamura, T., Hayakawa, M. \& Hatano, K. (1998). A new genus of the order Actinomycetales, Cryptosporangium gen. nov., with descriptions of Cryptosporangium arvum sp. nov. and Cryptosporangium japonicum sp. nov. Int J Syst Bacteriol 48, 9951005. 
Tamura, K., Dudley, J., Nei, M. \& Kumar, S. (2007). MEGA4: molecular evolutionary genetics analysis (MEGA) software version 4.0. Mol Biol Evol 24, 1596-1599.

Thompson, J. D., Gibson, T. J., Plewniak, F., Jeanmougin, F. \& Higgins, D. G. (1997). The CLUSTAL_X windows interface: flexible strategies for multiple sequence alignment aided by quality analysis tools. Nucleic Acids Res 25, 4876-4882.

Weon, H.-Y., Kim, B.-Y., Schumann, P., Kroppenstedt, R. M., Noh, H.-J., Park, C.-W. \& Kwon, S.-W. (2007). Knoellia aerolata sp. nov., isolated from an air sample in Korea. Int J Syst Evol Microbiol 57, 2861-2864.
Yokota, A., Tamura, T., Nishii, T. \& Hasegawa, T. (1993). Kineococcus aurantiacus gen. nov., sp. nov., a new aerobic, gram-positive, motile coccus with meso-diaminopimelic acid and arabinogalactan in the cell wall. Int J Syst Bacteriol 43, 52-57.

Zhi, X.-Y., Li, W.-J. \& Stackebrandt, E. (2009). An update of the structure and $16 \mathrm{~S}$ rRNA gene sequence-based definition of higher ranks of the class Actinobacteria, with the proposal of two new suborders and four new families and emended descriptions of the existing higher taxa. Int J Syst Evol Microbiol 59, 589-608. 